\title{
Menakar Kapasitas Adaptasi Perubahan Iklim Petani Padi Sawah (Kasus Kabupaten Pasuruan Jawa Timur)
}

\author{
Yudi L.A Salampessy ${ }^{1}$, Djuara P. Lubis ${ }^{2}$, Istiqlal Amien², Didik Suhardjito ${ }^{2}$ \\ ${ }^{1}$ Fakultas Pertanian Universitas Sultan Ageng Tirtayasa; e-mail: ysalampessy@gmail.com \\ 2 Fakultas Ekologi Manusia, Institut Pertanian Bogor \\ 2 Pusat Penelitian Agroklimat dan Hidrologi, Kementerian Pertanian RI \\ ${ }^{2}$ Fakultas Kehutanan, Institut Pertanian Bogor
}

\begin{abstract}
ABSTRAK
Perubahan iklim mensyaratkan kapasitas beradaptasi yang memadai dari petani karena pengelolaan SUT padi sawah sangat bergantung pada daya dukung iklim. Musim menjadi tidak menentu dan cuaca sulit diprediksi. Petani mulai kesulitan menentukan awal dan komoditas tanam, sementara serangan organisme pengganggu tanaman (OPT), banjir, dan kekeringan sebagai dampak negatif dari perubahan iklim semakin sering terjadi. Melalui survey terhadap 96 petani, penelitian ini menakar kapasitas beradaptasi perubahan iklim petani padi sawah di daerah pertanaman padi di dataran rendah, sedang, dan tinggi yang pernah menjadi wilayah percontohan program pengembangan kapasitas adaptasi perubahan iklim. Hasil penelitian menunjukkan kapasitas adaptasi petani padi sawah masih rendah dan memengaruhi tingkat penerapan adaptasi perubahan iklim mereka. Disarankan untuk dilakukan evaluasi terhadap strategi program-progran sejenis melalui penelitian mengenai faktor-faktor penentu kapasitas adaptasi perubahan iklim petani padi sawah.
\end{abstract}

Kata kunci: kapasitas adaptasi, padi sawah, perubahan iklim, petani

\begin{abstract}
Climate change requires adequate adaptation capability of farmers as the management of rice farming systems which is highly dependent on climate carrying a previously considered stable. Through a survey of 96 farmers, this study measured the adaptive capacity to climate change of rice farmers in the lowland, medium and highland rice cultivation areas as pilot zone in which improvement program in climate change adaptation has been established. The result shows rice farmers adaptive capacity is considered low and affects their adaptation level to climate change. It is necessary to evaluate the strategy of similar program by studying the determinant factors of climate change adaptation capacity of rice farmers.
\end{abstract}

Keywords: Adaptive capacity, climate change, farmer

Citation: Salampessy, Y.L.A., Lubis, D.P., Amien, I., Suhardjito, D. 2018. Menakar Kapasitas Adaptasi Perubahan Iklim Petani Padi Sawah (Kasus Kabupaten Pasuruan Jawa Timur). Jurnal Ilmu Lingkungan, 16(1), 25-34, doi:10.14710/jil.16.1.25-34

\section{Latar Belakang}

Usaha tani padi sawah sangat rentan terhadap dampak perubahan iklim karena keberhasilan usaha produksi pangan pokok ini sangat bergantung kepada daya dukung iklim yang sebelumnya dianggap stabi. Petani biasanya merujuk pada apa yang dalam bahasa Jawa dikenal sebagai pranåtåmångså (ketentuan musim), yaitu semacam penanggalan yang dikaitkan dengan kegiatan bercocok tanam. Dalam perkembangannya, kondisi iklim nyata maupun perkiraan kemudian menggeser ketentuan-ketentuan seperti itu. Hasil penelitian Syahbuddin et al. (2007) mengungkapkan bahwa dalam beberapa dekade terakhir usaha tani tanaman pangan seringkali hanya mengandalkan kebiasaan dan naluri (instinct) petanui dalam penetapan pola tanam. Akibatnya petani sering berhadapan dengan kendala kekurangan air, terutama pada saat musim kering yang berlangsung lebih lama. Oleh karena itu, perlu adanya penyesuaian pola tanam yang lebih adaptif dengan keragaman dan perubahan iklim.

Beberapa hasil penelitian mengungkapkan temperatur di Indonesia telah meningkat selama beberapa dekade belakangan dan diperkirakan akan terus meningkat sampai tahun 2020, serta adanya indikasi peningkatan level permukaan laut hingga tahun 2100 (IPCC 2007) yang dapat menyebabkan daerah-daerah dataran rendah di pinggir pantai seperti Surabaya memiliki resiko mengalami bencana banjir yang lebih tinggi (PEACE 2007). Selain itu, telah terjadi perubahan dalam musim hujan dan musim kemarau. Curah hujan pada musim hujan di wilayah bagian selatan Indonesia meningkat sementara curah hujan dimasa kemarau di wilayah bagian utara telah meningkat (Boer dan Faqih 2004, Naylor et al. 2007).

Menurut Lipińska (2016) dalam bidang pertanian kondisi cuaca seperti halnya perubahan 
Salampessy, Y.L.A., D.P. Lubis, I. Amien, D. Suhardjito. 2018. Menakar Kapasitas Adaptasi Perubahan Iklim Petani Padi Sawah (Kasus Kabupaten Pasuruan Jawa Timur). Jurnal Ilmu Lingkungan, 16(1), 25-34, doi:10.14710/jil.16.1.25-34 iklim memiliki dampak yang sama baik kepada kualitas maupun kuantitas produksi, termasuk pendapatan petani. FAO (2009) memperkirakan bahwa perubahan ini akan membuat krisis kemanusiaan yang ekstrim karena para petani bergantung pada kecukupan hujan untuk tanaman mereka. Mereka bergantung pada pola cuaca yang terduga untuk tanaman ketika menanam dan panen. Bagaimanapun perubahan iklim telah membuat varibialitas tak terduga dalam iklim. Hujan tidak beraturan dan peningkatan temperatur membuat usaha tani menjadi lebih menantang.

Perhitungan pengaruh perubahan iklim terhadap tanaman padi sawah di Indonesia oleh Handoko et al. (2008) memprediksi terjadinya penurunan produksi padi sawah di tahun 2050 sebesar 10.473 .764 ton atau $20.3 \%$ dari produksi pada tahun 2006 yang sebesar 51.647 .490 ton. Untuk wilayah Jawa Timur, pengaruh perubahan iklim yang mungkin terjadi terhadap pertanian padi telah diprediksi oleh Amien et al. (1996) akan terjadi pengurangan hasil produksi tanaman padi sekitar $1 \%$ per tahun. Oleh sebab itu penelitian dan pemanfaatan varietas padi yang toleran terhadap dampak perubahan iklim harus segera ditingkatkan untuk mengurangi resiko kehilangan hasil panen.

Kondisi iklim nyata dan perkiraan di atas menegaskan pentingnya kapasitas beradaptasi terhadap perubahan iklim bagi petani padi sawah. Akan tetapi kenyataan menunjukkan masih terdapat bermacam-macam pemahaman ataupun konseptualisasi yang diikuti oleh perbedaaan respon atas fenomena perubahan iklim, seperti yang diungkapkan Asplund (2014) bahwa melalui pengalamannya sendiri para petani memahami perubahan iklim sebagai proses alam yang tidak dipengaruhi oleh manusia. Selain itu masih terdapat pertentangan di antara petani dan masyarakat perdesaan mengenai perubahan iklim, seperti penggunaan terminologi perubahan iklim untuk berubahnya iklim berlawanan dengan variasi cuaca (Buys et al. 2011) dan perbedaan representasi perubahan iklim sebagai proses yang gradual berlawanan dengan proses yang tidak dapat diduga (Wibeck 2014).

Pentingnya kapasitas beradaptasi terhadap perubahan iklim petani padi sawah juga tersirat dalam hasil penelitian Naylor et al. (2007) yang fokus di dua area utama produksi padi di Indonesia, yaitu di Pulau Jawa dan Pulau Bali yang menunjukkan adanya peningkatan pengaruh Elnino terhadap penundaan musim hujan yang ditandai dengan kemungkinan penundaan selama 30 hari awal musim hujan pada tahun 2050. Prediksi dari siklus tahunan curah hujan menunjukkan adanya peningkatan curah hujan (10\%) diakhir tahun tanam (bulan April-Juni), tetapi suatu penurunan subtantif (hingga 75\%) dalam curah hujan diakhir musim kemarau (Juli dan September).

Pengembangan Kapasitas untuk Kegiatan Adaptasi Perubahan Iklim di Sektor Pertanian dan Sektor Lainnya yang Relevan (SP-2) di tingkat petani di Indonesia telah dilakukan pada tahun 2014 di desa-desa di Kecamatan Prigen, Purwosari, dan Gempol di Kabupaten Pasuruan Provinsi Jawa Timur. Wilayah-wilayah tersebut dipilih sebagai lokasi percontohan karena mewakili zona

dataran tinggi, menengah, dan rendah dari daerah pertanaman padi yang memiliki infrastruktur air yang cukup minim, serta selama ini terkena dampak perubahan iklim seperti banjir, kekeringan, dan organisme pengganggu tanaman (OPT). Program ini menyelenggarakan training of trainer (ToT) dan training of farmers (ToF) kegiatan adaptasi perubahan iklim kepada para penyuluh pertanian, pegawai dinas pertanian, pegawai Dinas PU/ Pengairan dan anggota kelompok-kelompok tani. Para peserta selanjutnya diharapkan mengadopsi dan mendifusikan kegiatan-kegiatan adaptasi perubahan iklim kepada para petani lainnya. Tujuannya adalah pengembangan kegiatan-kegiatan adaptasi perubahan iklim oleh komunitas petani untuk menurunkan tingkat kerugian akibat gagal panen yang disebabkan oleh perubahan iklim dan meningkatkan kesejahteraan petani.

Penelitian ini bertujuan untuk mendeskripsikan karakteristik terpilih, kapasitas beradaptasi dan pengaruhnya terhadap tingkat penerapan adaptasi perubahan iklim dari petani padi sawah di tiga lokasi percontohan tersebut.

\section{Metode Penelitian}

Penelitian dirancang sebagai penelitian survey di wilayah Kecamatan Gempol, Purwosari, dan Prigen di Kabupaten Pasuruan Jawa Timur. Ketiga wilayah secara berurut mewakili daerah pertanaman padi sawah pada zona agroekosistem dataran rendah, sedang, dan tinggi. Lokasi penelitian dipilih secara purposif sesuai tujuan penelitian berdasarkan kriteria khusus, yaitu kecamatan dengan desa-desa yang memiliki areal pertanaman padi sawah yang lebih luas, terdampak perubahan iklim, dan termasuk wilayah yang menjadi lokasi percontohan dari Program Pengembangan Kapasitas untuk Kegiatan Adaptasi Perubahan Iklim di Sektor Pertanian dan Sektor Lainnya yang Relevan (SP-2).

Populasi penelitian adalah seluruh petani padi sawah di 12 desa yang dipilih secara purposif dari ketiga kecamatan dengan pertimbangan memiliki dusun-dusun dengan areal pertanaman padi sawah yang lebih luas, terdampak perubahan iklim, serta memiliki kelompok tani yang mengikuti kegiatan peningkatan kapasitas adaptasi perubahan iklim. Jumlah populasi sebanyak 1.379 orang petani. Ukuran sampel ditetapkan sebanyak 96 orang petani yang terdiri dari 32 orang petani dari setiap kecamatan. Sampel ditarik dengan teknik acak sederhana secara proporsional berdasarkan proporsi jumlah petani di setiap dusun terpilih dan jumlah populasi petani desa-desa terpilih.

Data primer dikumpulkan melalui wawancara terstruktur dengan instrumen kuesioner yang telah diuji coba sebelumnya. Data sekunder dikumpulkan melalui wawancara lepas dan observasi lapangan untuk melengkapi data primer. Analisis data dilakukan secara deskriptif melalui penyusunan tabel tunggal dan secara inverensi melalui uji statistik korelasi Pearson Product Moment. 


\section{Hasil dan Pembahasan}

\subsection{Karakteristik terpilih responden}

Karakteristik responden yang diidentifikasi meliputi umur, jenis kelamin, tingkat pendidikan, lama berusaha tani, luas lahan garapan, orientasi SUT padi sawah, pola tanam, dan aksesibilitas adaptasi perubahan iklim.

\begin{tabular}{|c|c|c|}
\hline Karakteristik Responden & $\begin{array}{l}\text { Jumlah } \\
\text { (orang) }\end{array}$ & $\begin{array}{c}\text { Persen } \\
(\%)\end{array}$ \\
\hline \multicolumn{3}{|l|}{ Umur (tahun) } \\
\hline$<47$ & 34 & 35.4 \\
\hline $47-56$ & 36 & 37.5 \\
\hline$>56$ & 26 & 27.1 \\
\hline \multicolumn{3}{|l|}{ Jenis kelamin } \\
\hline Laki-laki & 86 & 89.6 \\
\hline Perempuan & 10 & 10.4 \\
\hline \multicolumn{3}{|l|}{ Tingkat pendidikan } \\
\hline SD & 44 & 45.8 \\
\hline SMP & 17 & 17.7 \\
\hline SMA & 29 & 30.2 \\
\hline PT & 6 & 6.2 \\
\hline \multicolumn{3}{|l|}{ Lama berusaha tani (tahun) } \\
\hline$<19$ & 36 & 37.5 \\
\hline $19-30$ & 34 & 35.4 \\
\hline$>30$ & 26 & 27.1 \\
\hline \multicolumn{3}{|l|}{ Luas lahan garapan $\left(\mathrm{m}^{2}\right)$} \\
\hline$<2.678$ & 46 & 47.9 \\
\hline $2.678-6.455$ & 34 & 35.4 \\
\hline$>6.455$ & 16 & 16.7 \\
\hline \multicolumn{3}{|l|}{ Aksesibilitas beradaptasi } \\
\hline Rendah & 37 & 38.5 \\
\hline Sedang & 33 & 34.4 \\
\hline Tinggi & 26 & 27.1 \\
\hline \multicolumn{3}{|l|}{ Orientasi SUT padi sawah } \\
\hline Konsumsi & 29 & 30.2 \\
\hline Konsumsi dan dijual & 67 & 69.8 \\
\hline \multicolumn{3}{|l|}{ Pola tanam (per tahun) } \\
\hline Padi-padi-padi & 41 & 42.7 \\
\hline Padi-padi (palawija)-palawija & 55 & 57.3 \\
\hline
\end{tabular}

Sumber: Pengolahan data primer

Data di atas menunjukkan karakteristik terpilih individu dari kebanyakan responden adalah petani padi sawah berjenis kelamin laki-laki, berumur cukup tua, telah lama berusaha tani, berpendidikan formal relatif rendah, dan kurang memiliki akses kepada komponen-komponen strategi adaptasi terhadap iklim. Selain itu SUT padi sawah yang dikelola kebanyakan responden termasuk kategori gurem dan subsiten.

\subsection{Kapasitas Adaptasi Perubahan Iklim Responden}

Kondisi iklim nyata maupun perkiraan kedepan menegaskan bahwa keberlangsungan SUT padi sawah di lokasi penelitian mensyaratkan kemampuan para petani untuk beradaptasi terhadap perubahan iklim. Kapasitas beradaptasi terhadap perubahan iklim responden diukur melalui tingkat pengetahuan strategi, sikap adaptif, dan tingkat keterampilan adaptasi terkait perubahan iklim.

\section{Pengetahuan adaptasi perubahan iklim}

Secara umum tingkat pengetahuan adaptasi perubahan iklim sebagian besar responden relatif belum sebanding dengan dampak perubahan iklim yang selama ini telah dirasakan melanda wilayah pertanaman padi sawah di lokasi penelitian. Hal ini terlihat dari sedikitnya jumlah responden dengan pengetahuan strategi beradaptasi yang termasuk dalam kategori tinggi.

Tabel 2. Distribusi responden berdasarkan pengetahuan adaptasi perubahan iklim

\begin{tabular}{lcc}
\hline \multicolumn{1}{c}{ Tingkat pengetahuan } & $\begin{array}{c}\text { Jumlah } \\
\text { (orang) }\end{array}$ & $\begin{array}{c}\text { Persen } \\
(\%)\end{array}$ \\
\hline Rendah & 21 & 21.9 \\
Sedang & 58 & 60.4 \\
Tinggi & 17 & 17.7 \\
\hline Total & 96 & 100 \\
\hline \multicolumn{2}{c}{ Sumber: Pengolahan data primer }
\end{tabular}

Pengetahuan adaptasi perubahan iklim responden yang relatif rendah terutama mengenai varietas padi sawah yang toleran terhadap rendaman, kekeringan, atau OPT tertentu yang dapat ditanam sebagai strategi untuk mengurangi dampak negatif perubahan iklim. Kebanyakan responden belum mengetahui nama dan keberadaan varietas-varietas padi tersebut karena belum pernah mendapatkan penjelasan atau menanamnya. Perubahan iklim juga kerap menimbulkan kebingungan di antara responden mengenai serangan OPT yang semakin beragam dan sulit dikendalikan, sampai-sampai beberapa responden mencoba mengendalikan serangan OPT dengan menyemprotkan tanaman padi mereka dengan cairan sabun pencuci, obat anti nyamuk, bahkan sampai dengan oli pelumas bekas pakai. Kondisi seperti ini sesuai dengan pendapat Rambo (1985) bahwa selain masih sedikitnya hal-hal nyata tentang ekosistem yang dipahami warga perdesaan tradisional, konseptualisasi ekosistem tersebut juga termasuk aspek yang sekarang tidak dipercaya sebenarnya ada.

Banyak responden juga kurang mengetahui keberadaan dan pentingnya informasi iklim. Para petani kebingungan mengenai musim dan menentukan awal dan komoditas tanam. Seorang petani yang sangat senior, telah lama menjadi ketua kelompok tani, serta sering dijadikan nara sumber sekalipun hanya dapat menjawab pertanyaan petani mengenai kejelasan musim dengan kalimat "ono hujan yoo rendeng, ora ono yoo ketigo, karepe pangeran (ada hujan berarti musim penghujan, tidak ada berarti musim kemarau, terserah Tuhan)". Contoh lainnya adalah seorang ketua kelompok tani memutuskan untuk menebas tanaman padinya yang masih muda karena kekurangan air dan menugaskan anggota kelompok untuk mencari benih kacang hijau. Setelah tanaman padi ditebas dan lahan dibersihkan ternyata hujan turun di malam hari. Diperkirakannya hujan hanya turun sekilas saja, tetapi tiga hari kemudian hujan turun kembali. Kedua contoh tersebut cukup memprihatinkan karena melibatkan ketua kelompok tani yang seharusnya menjadi panutan bagi anggotanya. 
Salampessy, Y.L.A., D.P. Lubis, I. Amien, D. Suhardjito. 2018. Menakar Kapasitas Adaptasi Perubahan Iklim Petani Padi Sawah (Kasus Kabupaten Pasuruan Jawa Timur). Jurnal Ilmu Lingkungan, 16(1), 25-34, doi:10.14710/jil.16.1.25-34

Pengetahuan responden mengenai pengelolaan air irigasi, pengolahan tanah dan pergiliran tanaman sebagai strategi menghadapi perubahan iklim sudah cukup baik. Akan tetapi pengetahuan mengenai teknologi penyimpanan air untuk menghadapi musim kemarau yang panjang masih kurang. Hal ini dikarenakan Kabupaten Pasuruan sejak dulu memang dikenal sebagai daerah yang banyak memiliki sumber air yang berkualitas dan mampu memasok kebutuhan air masyarakat sampai ke Surabaya. Sampai saat ini pun beberapa perusahaan besar yang berbahan baku air bersih memiliki pabrik pengolahan di sekitar lokasi penelitian. Oleh sebab itu petani tidak memiliki tradisi penyimpanan air. Bagi petani, kekurangan air pada saat musim kemarau lebih mudah diatasi dengan mengambil air "glondongan" (air irigasi dari bendungan Joko Tirto di daerah Lawang).

Merujuk pada penjelasan informan di Kecamatan Pandaan yang terletak di tengah ketiga kecamatan lokasi penelitian, secara historis ketersediaan air dari sumber-sumber air di gunung Arjuno (berdekatan dengan Kecamatan Purwosari) dan Gunung Penanggungan (berdekatan dengan Kecamatan Prigen) dialirkan sampai ke Kecamatan Gempol yang merupakan dataran paling rendah. Hal ini bisa dilihat dari situs-situs sejarah seperti candi Jawi dan Candi Tetek yang berkaitan dengan pengelolaan air sejak jaman kerajaan Majapahit yang saluran irigasinya banyak ditemukan sampai saat ini. Bahkan di wilayah Kabupaten Mojokerto (berbatasan dengan Kecamatan Gempol dan Prigen) terdapat situs bersejarah yang konon merupakan sebuah kolam besar (embung) tempat para raja Majapahit menjamu tamu kerajaan sambil menunjukkan ketersediaan air sebagai simbol dari kesejahteraan.

Deskripsi di atas menjadi penting karena menjelaskan strategi beradaptasi perubahan iklim yang telah diketahui dan yang belum diketahui para petani di lokasi penelitian. Informasi seperti ini bukan saja dapat membuka pikiran pemerintah terhadap pengetahuan lingkungan yang sudah dimiliki oleh penduduk desa yang dapat melengkapi pengetahuan ilmuan saat ini (Rambo 1985), tetapi juga menjadi bahan evaluasi kesesuaian startegi peningkatan kapasitas adaptasi perubahan iklim yang dilaksanakan oleh para pemangku kepentingan.

\section{Sikap adaptif perubahan iklim}

Sikap adaptif terhadap perubahan iklim kebanyakan responden termasuk kategori sedang. Walaupun proporsi responden dalam kategori sikap adaptif yang tinggi cukup besar, akan tetapi masih cukup banyak responden dengan kategori sikap adaptif perubahan iklim yang rendah yang menunjukkan kecenderungan beradaptasi terhadap perubahan iklim yang juga rendah.

Tabel 3. Distribusi responden berdasarkan sikap adaptif perubahan iklim

\begin{tabular}{lcc}
\hline Sikap adaptif & $\begin{array}{c}\text { Jumlah } \\
\text { (orang) }\end{array}$ & $\begin{array}{c}\text { Persen } \\
(\%)\end{array}$ \\
\hline Rendah & 27 & 28.1 \\
Sedang & 39 & 40.6 \\
Tinggi & 30 & 31.2 \\
\hline Total & 96 & 100 \\
\hline \multicolumn{2}{c}{ Sumber: Pengolahan data primer } &
\end{tabular}

Rendahnya sikap adaptif perubahan iklim responden banyak terkait dengan penilaian mereka atas untung ruginya penerapan strategi beradaptasi terhadap perubahan iklim. Banyak diantara petani yang tidak setuju mengistirahatkan lahan padi sawahnya selama satu musim karena sama dengan menghilangkan penghasilan mereka. Di lokasi-lokasi penelitian dimana air irigasi tersedia sepanjang tahun, menggilir tanaman antar musim dinilai merugikan karena beras dibutuhkan keluarga dan menanam padi lebih menguntungkan dibandingkan komoditas lainnya. Pada sisi lain kegiatan tersebut justru merupakan strategi baku yang cukup ampuh untuk untuk mengembalikan unsur hara tanah dan memotong siklus hidup OPT sehingga dapat mencegah serangan OPT yang semakin beragam dan sulit dikendalikan seperti yang mereka keluhkan deawasa ini. Hal ini sesuai dengan temuan penelitian Puupponen et al. (2015) yang menunjukkan bahwa penerimaan sosial kebijakan adaptasi bergantung pada derajat keterbatasan dan perhitungan akibat kebijakan tersebut pada keuntungan dari usaha pertanian dan makanan.

Kebanyakan responden menyetujui bahwa keberhasilan usaha tani padi sawah ditentukan oleh teknologi budidaya padi sawah yang sesuai dengan sebagian strategi beradaptasi terhadap perubahan iklim seperti penanaman serentak, bahwa penggunaan pupuk atau pestisida berbahan organik adalah lebih baik daripada yang berbahan kimia, serta penyesuaian SUT dengan kondisi cuaca. Akan tetapi pada saat yang bersamaan sebagian responden juga menyetujui bahwa daya dukung iklim terhadap usaha tani padi sawah ditentukan oleh Tuhan, tidak dapat dirubah oleh manusia, dan terkait dengan perilaku negatif manusia. Sikap ini sepertinya banyak didasari oleh kultur agamis masyarakat Kabupaten Pasuruan yang memang dikenal sebagai kota santri karena memiliki banyak pesantren.

Jika dicermati lebih dalam, hasil penelitian dan pengamatan di lapangan mengindikasikan bahwa sikap tersebut terbentuk lebih dikarenakan kurangnya pengetahuan responden atas isu-isu perubahan iklim. Utamanya karena sikap adaptif kebanyakan responden lebih mengarah kepada sikap ilmiah ketika terkait dengan pengalaman teknologi budidaya padi sawah, tetapi cenderung mengarah pada sikap fatalis ketika terkait dengan pengalaman iklim. Dimana teknologi budidaya padi sawah adalah sesuatu yang mereka selalu cari dan terapkan, sedangkan perubahan iklim masih menjadi isu baru bagi kebanyakan orang. Terkait dengan itu Lorenzoni et al. (2007) menjelaskan bahwa tingkat keterlibatan petani dalam perubahan iklim terkait pada pengetahuan dasar, nilai-nilai, pengalaman, dan gaya hidup dan semua itu pada gilirannya dipengaruhi oleh luasnya tataran kemasyarakatan.

\section{Keterampilan adaptasi perubahan iklim \\ Kebanyakan responden memiliki keterampilan} adaptasi perubahan iklim yang termasuk dalam 
kategori sedang. Akan tetapi masih cukup banyak responden yang memiliki keterampilan beradaptasi yang rendah. Kondisi ini dikarenakan jarang diselenggarakannya kegiatan-kegiatan bimbingan atau pelatihan yang terkait langsung dengan strategi adaptasi perubahan iklim kepada para petani, baik di kelompok tani maupun di tempat-tempat lainnya. Kalupun ada, tidak semua petani dapat hadir atau dilibatkan dalam kegiatan seperti itu.

Tabel 4. Distribusi responden berdasarkan keterampilan adaptasi perubahan iklim

\begin{tabular}{lcc}
\hline Tingkat keterampilan & $\begin{array}{c}\text { Jumlah } \\
\text { (orang) }\end{array}$ & $\begin{array}{c}\text { Persen } \\
(\%)\end{array}$ \\
\hline Rendah & 30 & 31.2 \\
Sedang & 38 & 39.6 \\
Tinggi & 28 & 29.2 \\
\hline Total & 96 & 100 \\
\hline Sumber: Pengolahan data primer &
\end{tabular}

Keterampilan kerja di luar sektor pertanian menjadi keterampilan yang paling rendah dari kebanyakan responden yang selama ini hanya menekuni usaha tani padi sawah sebagai pekerjaan utama. Beberapa responden memang sering mendapatkan pelatihan kerja di luar sektor pertanian, seperti perternakan, perikanan, dan perkebunan dari pihak-pihak terkait, tetapi semua itu lebih kepada upaya peningkatan kesejahteraan petani sehingga petani kurang menyadari bahwa pembelajaran tersebut merupakan salah satu strategi beradaptasi terhadap perubahan iklim. Menurut para penyuluh pertanian, selain mereka sendiri tidak memiliki tupoksi dan keahlian ke arah itu, memberikan pelatihan kerja di luar sektor pertanian kurang produktif bagi kebanyakan petani walaupun terkait dengan strategi adaptasi perubahan iklim. Banyak petani tetap akan bertani dalam kondisi iklim seperti apapun karena hanya itu yang mereka punya dan bisa. Sedangkan, Smit dan Wandel (2006) mencatat bahwa untuk sistem pertanian yang menghadapi terpaan kekurangan air, adaptasi sederhana mungkin dengan lebih menggunakan tanaman resisten kekeringan, adaptasi yang lebih substansial mungkin beralih dari menanam menjadi beternak, dan adaptasi yang lebih substansial lagi mungkin mengabaikan keduanya.

Keterampilan petani dalam pengelolaan air untuk mencegah kekeringan atau banjir sangat bergantung pada letak dan kondisi geografis wilayahnya, serta kondisi irigasi yang ada. Pada dasarnya keterampilan pengairan sudah melekat dalam usaha tani padi sawah karena memang sudah dilakukan turun-temurun. Oleh sebab itu informasi atau pelatihan mengenai pengelolaan air kurang dibutuhkan, sudah sering dibahas dalam diskusi kelompok tani, atau disampaikan oleh pihak penyuluh maupun pihak lainnya sehingga petani sudah cukup terampil dalam pengelolaan lahan dan air. Permasalahan baru muncul ketika dari tahun ke tahun debit air dari sumber air dirasakan menurun akibat musim yang sering tidak menentu. Pengolahan lahan menjadi sulit dilakukan walaupun petani memiliki keterampilan yang cukup, padahal jika pengolahan lahan kurang matang (kurang maksimal), produktivitas lahan akan menurun. Sedangkan berkurangnya ketersediaan air pada saat musim kemarau tidak menjadi masalah karena memang saatnya bagi petani untuk menanam palawija.

Untuk daerah yang lebih tinggi seperti di dusun Lumbang dan Pecalukan di Kecamatan Prigen, air cukup tersedia baik secara kuntitas maupun kualitas. Melalui swadaya masyarakat serta informasi, bimbingan, dan pendampingan dari penyuluh pertanian dan pihak lainnya seperti pemerintah daerah dan JICA, bangunan, pemeliharaan, dan pemanfaatan air menjadi semakin baik (pipanisasi dan pembagian waktu pengairan). Air dari sumbernya dapat terdistribusi ke semua penduduk untuk kebutuhan rumah tangga maupun mengairi sawah. Akan tetapi jenis tanah di daerah-daerah tersebut menyebabkan air cepat hilang (meresap) ke dalam lahan maupun saluran pengairan sehingga dibutuhkan banyak air untuk mengolah lahan (ngurit). Demikian halnya dengan para petani di Dusun Bulusari Kecamatan Gempol yang mampu mengurangi resapan air irigasi ke dalam tanah dengan memanfaatkan belahan tong untuk melapisi saluran irigasi dan mengendalikan kelebihan debit air melalui buka tutup pintu air.

Keterampilan adaptasi perubahan iklim yang paling dibutuhkan responden adalah yang terkait dengan keterampilan pengendalian serangan OPT yang semakin beragam, serta pengelolaan tanaman dalam kondisi cuaca yang tidak menentu karena keduanya sangat memengaruhi tingkat produktivitas lahan padi sawah saat ini. Kebanyakan petani memperoleh keterampilan pengendalian OPT dari keterlibatannya dalam Sekolah Lapang Pengendalian Hama Terpadu (SLPHT) yang terjadwal dengan baik di setiap kecamatan. yang diselenggarakan oleh para penyuluh pertanian di tempat atau sawah salah satu kelompok tani dan dihadiri oleh seluruh kelompok tani anggota setiap gabungan kelompok tani. Pendekatan ini cukup berhasil meningkatkan keterampilan responden dalam pengendalian OPT, karena pendekatan berbasis tempat untuk berdiskusi dampak perubahan iklim pada spesifik area, komunitas, dan lokasi menjanjikan penyampaian pesan menjadi lebih efektif (Grossman 2005, Thompson dan Schweizer 2008).

Keterampilan pengendalian OPT juga didapatkan petani melalui pertemuan-pertemuan yang difasilitasi pihak Badan Penyuluhan Pertanian (BPP) kecamatan dengan nara sumber penyuluh pertanian, para ahli, atau para petani penyuluh swadaya yang memiliki keahlian dalam membuat pupuk dan pestisida organik untuk pengendalian OPT. Selain itu para petani juga terbiasa mendatangi langsung para penyuluh swadaya tersebut untuk mendapatkan pupuk dan pestisida organik sekaligus bimbingan penggunaannya. Termasuk berkonsultasi dalam kondisi darurat ketika lahan padi sawah yang digarapnya terserang OPT yang belum pernah ada sebelumnya atau yang sulit dikendalikan.

Berbeda dengan keterampilan dalam pengendalian OPT, banyak responden belum memiliki keterampilan pengelolaan tanaman padi 
Salampessy, Y.L.A., D.P. Lubis, I. Amien, D. Suhardjito. 2018. Menakar Kapasitas Adaptasi Perubahan Iklim Petani Padi Sawah (Kasus Kabupaten Pasuruan Jawa Timur). Jurnal Ilmu Lingkungan, 16(1), 25-34, doi:10.14710/jil.16.1.25-34 sawah dalam cuaca yang tidak menentu. Hal ini disebabkan sebagian besar responden tidak pernah mengikuti sekolah iklim yang memang jarang sekali diselenggarakan di tempat-tempat yang dekat dengan lokasi penelitian. Berdasarkan penjelasan beberapa responden diketahui bahwa informasi mengenai perubahan iklim memang disebarkan oleh petani dan penyuluh pertanian yang pernah mengikuti kegiatan-kegiatan sejenis sekolah iklim. Oleh sebab itu para petani mungkin mengetahui terjadinya perubahan iklim dan pengaruhnya terhadap SUT padi mereka, tetapi belum tentu terampil mengatasinya karena tidak dilanjutkan dengan adanya program pendampingan ataupun pelatihan seperti pemanfaatan kalender tanam dan penanaman varietas-varietas yang toleran terhadap dampak perubahan iklim. Hal ini bisa terlihat dari kebingungan responden dalam mendefinisikan musim berjalan, serta menentukan waktu dan komoditas tanam.

Kondisi di atas sejalan dengan hasil penelitian Mabe et al. (2012) yang mengungkapkan bahwa petani padi harus dikuatkan melalui layanan penyuluhan yang lebih baik untuk mencapai kapasitas adaptasi yang tinggi juga untuk menolong mereka memperoleh output padi yang lebih. Lipińska (2016) menjelaskan bahwa biasanya para petani dapat menentukan apakah akan berpartisipasi dalam program pemerintah di setiap tahun. Partisispasi dalam satu program mungkin membutuhkan partisipasi dalam program-program aplikasi lainnya. Bagaimanapun para petani dapat menganalisis efek potensial berpartisipasi atau tidak berpartisipasi berdasarkan lingkungan individual mereka dan spesifikasi setiap program. Partisipasi mungkin menguntungkan di beberapa tahun dan tidak di tahun lainnya. Dengan demikian peningkatan keterampilan beradaptasi perubahan iklim para responden dapat dilakukan dengan meningkatkan partisipasi responden dalam kegiatan-kegiatan pendidikan, pelatihan, dan konsultasi perubahan iklim di sektor pertanian. Untuk itu frekuensi penyelenggaraan kegiatan-kegiatan sejenis di lokasi penelitian harus lebih ditingkatkan.

Terkait dengan kapsitas adaptasi petani terhadap perubahan iklim, hasil-hasil penelitian Hassan dan Nhemachena (2008), Ozor dan Cynthia (2011), Esham dan Garforth (2012) mengungkapkan bahwa kapasitas petani beradaptasi terhadap perubahan iklim banyak ditentukan oleh variabel-variabel seperti kondisi agroekologi, karakteristik sosial-ekonomi, penyuluhan, dan partisipasi para petani. Sedangkan Chérif dan Greenberg (2013) menegaskan bahwa jika ingin sukses strategi adaptasi harus mempertimbangkan dan harus berawal dari suatu pemahaman bagaimana pengalaman dan pikiran para petani lokal mengenai manifestasi perubahan iklim yang terlihat.

\subsection{Hubungan kapasitas beradaptasi dan tingkat penerapan adaptasi perubahan iklim}

Secara umum adaptasi terhadap perubahan iklim relatif belum diterapkan oleh sebagian besar responden. Masih cukup banyak responden dengan tingkat penerapan adaptasi perubahan iklim yang termasuk

dalam kategori rendah dan yang lainnya kebanyakan termasuk masuk pada kategori sedang.

Tabel 5. Distribusi responden berdasarkan tingkat penerapan adaptasi perubahan iklim

\begin{tabular}{lcc}
\hline Tingkat penerapan & $\begin{array}{c}\text { Jumlah } \\
\text { (orang) }\end{array}$ & $\begin{array}{c}\text { Persen } \\
(\%)\end{array}$ \\
\hline Rendah & 32 & 33.3 \\
Sedang & 36 & 37.5 \\
Tinggi & 28 & 29.2 \\
\hline Total & 96 & 100 \\
\hline Sumber: Pengolahan data primer &
\end{tabular}

Pada dasarnya secara naluriah para petani akan selalu menyesuaikan pengelolaan SUT padi sawah dengan kondisi iklim, karena sebagai tanaman semusim padi sawah sangat bergantung pada lingkungan alam sehingga rentan terhadap berbagai resiko terkait kondisi alam. Perubahan iklim akan menyebabkan cekaman pada tanaman padi, terutama cekaman air yang pada akhirnya dapat menurunkan tingkat produksi SUT padi sawah. Dengan demikian tingkat penerapan adaptasi perubahan iklim banyak responden harus segera ditingkatkan. Salah satunya adalah dengan mendalami apa yang telah dilakukan petani dalam merespon perubahan iklim dan menganalisis faktor-faktor penentunya.

Pengamatan langsung di lokasi penelitian menunjukkan bahwa banyak strategi beradaptasi terhadap perubahan iklim yang menjadi sulit diterapkan oleh para petani karena tidak sesuai dengan letak serta kondisi geografis dan sosial-ekonomi para petani. Sebagai contoh penggunaan sumur bor untuk mengairi sawah pada saat kekeringan tidak dapat diterapkan di dataran tinggi seperti Kecamatan Prigen. Di Desa Bakalan dan Martopuro di Kecamatan Purwosari yang sering dilanda kekeringan, tidak semua tempat mudah untuk dibor karena lapisan tanah di bawahnya berbatuan dan ijin pengeboran relatif sulit didapat. Biaya pengeboran air tanah menjadi mahal dan menambah tinggi biaya usaha tani padi sawah. Oleh sebab itu para petani lebih memilih meminta "glondongan" (air irigasi dari bendungan) yang relatif lebih murah daripada mengebor air tanah. Menariknya, informasi dari perangkat desa menjelaskan bahwa yang sebenarnya terjadi belakangan ini bukanlah kekeringan, tetapi salah mongso (salah musim) sehingga banyak petani salah memprediksi awal dan komoditas tanam.

Dusun Ngelawang dan Watukosek di Desa Watukosek Kecamatan Gempol adalah dusun yang sering dilanda kekeringan. Jauh sebelumnya daerah-daerah ini berkecukupan air sehingga tidak mengenal teknologi penyimpanan air. Lokasi yang berdekatan dengan pabrik industri termasuk industri air kemasan, menyebabkan debit air dari sumber air yang dulunya berlimpah menjadi jauh berkurang. Banyak petani tidak bisa mengebor air tanah karena berbiaya dan air juga akan mengairi sawah petani lain padahal tidak semua petani mau ikut menanggung biaya tersebut. Dusun ini pernah mendapatkan bantuan sumur bor untuk pengairan sawah dari pemerintah daerah, akan tetapi belum 
dapat memenuhi kebutuhan petani. Jika dipaksakan memang kebutuhan pengairan sawah tercukupi, tetapi debit air sumur warga menjadi jauh berkurang. Akhirnya anggota kelompok tani bersepakat untuk tidak menggarap sawah pada musim tanam kedua, sedang musim tanam ketiga memang saatnya untuk menanam palawija. Ketika diperkenalkan dengan teknologi penyimpanan air seperti embung misalnya, perhatian petani bukan kepada teknologinya, tetapi lebih kepada lahan siapa yang mau digunakan dan siapa yang menanggung biaya pembuatannya. Sebaliknya, pada puncak musim hujan dusun ini sering terendam banjir. Penggunaan pompa air untuk mengurangi genangan banjir menjadi sia-sia karena banjir disebabkan oleh letak geografis yang rendah dan pendangkalan sungai Porong akibat luapan lumpur Lapindo yang menyebabkan air hujan dan air limpasan yang melalui dusun tersebut tidak dapat mengalir dengan cepat.

Pergiliran tanam padi dan palawija serta mengistirahatkan lahan untuk memotong siklus hidup OPT dan mengembalikan unsur hara dalam tanah juga sangat jarang dilakukan oleh responden di sebagian besar wilayah Kecamatan Purwosari dan Gempol. Hal ini karena dianggap sama dengan menghilangkan pendapatan mereka, padahal air cukup tersedia sepanjang tahun untuk berusaha tani padi sawah. Sedangkan menanam selain tanaman pangan seperti tanaman sayuran dan tanaman perkebunan hanya bisa dilakukan oleh para petani yang memiliki lahan cukup luas. Selain itu juga enggan dilakukan oleh petani gurem karena orientasi penanaman padi sawah adalah untuk memenuhi kebutuhan pangan pokok keluarga.

Keterlibatan langsung di lokasi penelitian menunjukkan bahwa pesan-pesan pengendalian OPT cukup sering dikomunikasikan secara terjadwal di seluruh kecamatan melalui SLPHT. Bahkan Kecamatan Purwosari dan Gempol memiliki petani yang berhasil menciptakan pupuk dan pestisida organik serta menjadi sumber informasi pengendalian OPT bagi banyak petani. Akan tetapi teknologi seperti ini hanya diterapkan oleh sebagian kecil petani. Banyak petani yang kurang percaya atau merasa cara-cara seperti itu kurang praktis, sedangkan pupuk dan pestisida kimia sudah dirasakan ampuh dalam membasmi OPT walaupun dewasa ini mulai dirasakan menurun keampuhannya. Bagi petani, paling tidak pupuk dan pestisida kimia lebih mudah didapatkan dan digunakan. Bahkan di antara antara petani dikenal jargon "mati urip urea" (mati hidup, urea). Kondisi ini serupa dengan hasil penelitian Skambraks (2014) yang menunjukkan bahwa kebanyakan petani tidak beradaptasi terhadap perubahan iklim karena kesadarannya atas kebutuhan untuk beradaptasi dan kapasitas adaptasinya rendah.

Penggunaan varietas toleran terkendala oleh karakteristik subsiten dari kebanyakan petani. Mereka lebih senang memilih varietas padi sawah yang menghasilkan beras yang rasanya sesuai dengan selera seperti varietas Ciherang, IR64, dan Marlboro (Way Apo Buru ), walaupun varietas-varietas tersebut kurang toleran atau memiliki spesifikasi tertentu terhadap dampak perubahan iklim. Oleh sebab itu varietas lainnya termasuk varietas yang toleran dengan dampak perubahan iklim seperti Gajah Mungkur, Inpara, dan Memberamo tidak akan ditanam jika menghasilkan beras yang rasanya tidak sesuai dengan selera makan mereka. Bagi sebagian petani untuk apa bekerja keras di sawah jika hasilnya keras di lidah. Hambatan lainnya adalah beberapa varietas lain kurang laku dijual karena kualitas beras yang tidak sesuai dengan permintaan konsumen, sehingga pihak penggilingan juga sering menolak permintaan jasa giling karena setelah digiling biasanya dijual petani kepada pihak penggilingan. Kenyataan ini sesuai dengan hasil penelitian Peñalba et al. (2012) yang mengungkapkan bahwa kesadaran akan perubahan iklim dan dampaknya mungkin tidak berubah menjadi aksi-aksi diantaranya karena alasan-alasan sosial dan ekonomi.

Pemanfaatan informasi iklim termasuk kalender tanam hanya bisa dilakukan oleh sebagian besar petani dengan menanyakannnya kepada para penyuluh pertanian. Untuk memanfaatkan media dalam jaringan informasi kebanyakan petani terkendala dengan aksesibilitas pemanfaatan jaringan internet. Sedangkan siaran televisi dan radio lebih banyak dimanfaatkan anggota keluarga sebagai media hiburan, dibandingkan sebagai media informasi perubahan iklim yang pemberitaannya juga relatif jarang. Lebih dari itu, masih banyak petani yang meragukan akurasi informasi iklim yang mereka terima karena sering berbeda dengan kenyataan dan mereka kurang memiliki pengetahuan tentang isu-isu perubahan iklim.

Bekerja di luar sektor pertanian ketika usaha tani sulit dilakukan menjadi salah satu strategi beradaptasi yang paling sulit untuk diterapkan. Kecuali oleh mereka yang memiliki modal usaha, cukup berpendidikan, memiliki ternak, atau memiliki keahlian tertentu. Masih banyak petani yang hanya memiliki keahlian bertani yang telah dipelajarinya secara turun-temurun. Sedangkan untuk membekali diri dengan keterampilan kerja di luar sektor pertanian relatif sulit dilakukan karena terhambat oleh faktor usia serta ketersediaan waktu dan biaya. Oleh sebab itu sebagian responden biasanya hanya bisa bekerja secara serabutan.

Kenyataan ini menunjukkan bahwa kegiatan adaptasi banyak responden selama ini lebih berkisar kepada teknologi budidaya padi yang lazim dilakukan secara turun temurun dalam pengelolaan SUT padi sawah yang secara kebetulan juga sesuai dengan sebagian strategi beradaptasi terhadap perubahan iklim yang dikembangkan secara ilmiah dewasa ini, seperti menggilir komoditas tanam karena pergantian musim, menentukan awal tanam berdasarkan kondisi cuaca, memelihara saluran irigasi, menanam serentak dengan petani lainnya, mengawasi pertumbuhan tanaman, dan sebagainya. Penerapan adaptasi seperti ini termasuk dalam kategori adaptasi reaktif, yaitu adaptasi yang diimplementasikan setelah dampak perubahan iklim telah dirasakan (Dolan et al. 2001). 
Salampessy, Y.L.A., D.P. Lubis, I. Amien, D. Suhardjito. 2018. Menakar Kapasitas Adaptasi Perubahan Iklim Petani Padi Sawah (Kasus Kabupaten Pasuruan Jawa Timur). Jurnal Ilmu Lingkungan, 16(1), 25-34, doi:10.14710/jil.16.1.25-34

Tabel 6. Hasil uji korelasi

\begin{tabular}{lcc}
\hline Kapasitas Beradaptasi & $\begin{array}{c}\text { Koefisien } \\
\text { Korelasi (r) }\end{array}$ & $\begin{array}{c}\text { Nilai } \\
\text { Peluang }\end{array}$ \\
\hline Tingkat pengetahuan & 0.52 & $0.00^{* *}$ \\
Sikap adaptif & 0.42 & $0.00^{* *}$ \\
Tingkat keterampilan & 0.67 & $0.00^{* *}$ \\
\hline Sumber: Pengolahan data primer &
\end{tabular}

Nilai koefisien korelasi yang positif serta nilai peluang yang lebih kecil dari taraf nyata $(\alpha)=1 \%$ pada tabel di atas menunjukkan bahwa kapasitas beradaptasi perubahan iklim responden memiliki hubungan positif dan sangat nyata secara setatistik dengan tingkat penerapan adaptasi perubahan iklim responden. Dapat diinterpretasikan bahwa jika ada peningkatan kapasitas beradaptasi terhadap perubahan iklim pada responden, pada saat yang sama penerapan adaptasi perubahan iklim oleh responden juga meningkat.

Interpretasi tersebut menunjukkan bahwa di tengah cekaman serta kebaruan dan kompleksitas isu perubahan iklim, peningkatan kapasitas beradaptasi terhadap perubahan iklim merupakan titik kritis bagi penerapan adaptasi perubahan iklim oleh petani untuk dapat menjaga dan meningkatkan produksi SUT padi sawah mereka dan ketahanan pangan lokal. Hal ini sejalan dengan pernyataan Wamsler dan Brink (2015) bahwa terdapat sebuah konsensus yang berkembang terkait sangat pentingnya kapasitas adaptasi individu untuk keberhasilan adaptasi perubahan iklim dan capaian pembangunan berkelanjutan. Merujuk pada Adger et al. (2009) bahwa faktor-faktor sosial dan individual membatasi aksi adaptasi, maka selain dikarenakan faktor-faktor sosial, kondisi ini bisa disebabkan oleh kurangnya pengetahuan, sikap, dan keterampilan individu petani terkait perubahan iklim.

Penelitian Dang (2014) menunjukkan bahwa jika petani memiliki penerimaan yang lebih tinggi atas resiko perubahan iklim atau penerimaan yang lebih besar atas keefektivan langkah adaptif, mereka lebih mungkin berniat untuk beradaptasi. Sebaliknya, ketika petani memiliki andai-andai, menyangkal resiko perubahan iklim atau fatalisme (yaitu maladaptasi), mereka kurang mungkin untuk memiliki niat beradaptasi. Sejalan dengan itu penelitian Arbuckle et al. (2013) menunjukkan bahwa para petani yang percaya bahwa perubahan iklim telah terjadi dan dapat diatribusikan kepada aktivitas manusia, secara signifikan lebih mungkin untuk mengekspresikan perhatian mengenai dampak dan mendukung kegiatan adaptif dan mitigatif. Pada sisi lain, para petani yang mengatributkan perubahan iklim disebabkan oleh alam, kurang mendukung adaptasi dan semakin kurang mungkin untuk membantu kegiatan mitigasi pemerintah dan individu. Sedangkan menurut Asante et al. (2012), kekurangan pelatihan dan para ahli dapat membatasi kemampuan rumah tangga, komunitas, atau bangsa untuk menerapkan pilihan-pilihan adaptasi.

Wamsler dan Brink (2015) menjelaskan bahwa untuk menterjemahkan kapasitas adaptasi ke dalam adaptasi, intervensi terencana dan bertarget dibutuhkan untuk menyediakan dukungan yang lebih baik untuk praktek adaptasi masyarakat pada level lokal. Akan tetapi terdapat banyak tantangan yang terasosiasi dengan mengkomunikasikan sains perubahan iklim (Weber 2010, Weber dan Stern 2011) dan ini khususnya terbukti dalam sektor agribisnis (Rejesus et al. 2013). Termasuk variasi dari faktor sosial dan kultural yang memengaruhi keyakinan individual mengenai perubahan iklim dan keinginan untuk memanfaatkan sains iklim dalam membuat keputusan (Hoffman 2011, Nisbet 2009). Oleh sebab itu sains iklim perlu dikomunikasikan dengan serius dalam rangka memastikan bahwa sektor agribisnis mengenali nilai adaptasi dan mitigasi resiko ketidakpastian yang efektif yang diasosiasikan dengan berubahnya iklim (Moser 2010, Nisbet 2009). Salah satu tujuannya adalah untuk menanamkan pemahaman mengenai lingkungan, sikap positif terhadap lingkungan, kompetensi aksi warga negara, dan dalam artian pemberdayaan (Monroe et al. 2000).

\section{SIMPULAN DAN SARAN}

\section{Simpulan}

1. Kapasitas adaptasi perubahan iklim sebagian besar responden relatif masih rendah. Banyak responden belum memiliki pengetahuan adaptasi perubahan iklim yang dikembangkan dewasa ini. Responden lebih bersikap adaptif terhadap teknologi budidaya padi sawah, tetapi kurang adaptif terhadap kondisi iklim dan lingkungan. Selain itu Keterampilan beradaptasi responden juga relatif rendah. Kebanyakan responden jarang mengikuti kegiatan pelatihan adaptasi perubahan iklim.

2. Tingkat penerapan adaptasi perubahan iklim responden relatif masih rendah. Kegiatan Adaptasi responden lebih bersifat reaktif daripada antisipatif. Beberapa strategi beradaptasi terhadap perubahan iklim yang dikembangkan secara ilmiah dewasa ini tidak bisa diterapkan karena belum diketahui, berbiaya, atau kurang sesuai dengan letak dan kondisi geografis lokasi penelitian.

3. Kapasitas beradaptasi terhadap perubahan iklim memengaruhi tingkat penerapan adaptasi perubahan iklim responden. Jika ada peningkatan kapasitas beradaptasi, pada saat yang sama penerapan adaptasi perubahan iklim oleh responden juga meningkat

\section{Saran}

1. Dilakukan evaluasi terhadap program-program yang bertujuan meningkatan kapasitas beradaptasi petani terhadap perubahan iklim yang selama ini telah dilaksanakan di lokasi penelitian

2. Pemerintah memastikan penyebaran informasi perubahan iklim sampai di tingkat petani dan menyusun serta menyelenggarakan program-program pembangunan pertanian berperspektif adapatasi perubahan iklim di setiap level pengambil kebijakan pembangunan 
pertanian dan melibatkan para pihak termasuk media massa

3. Seluruh upaya peningkatan kapasitas adaptasi petani terhadap perubahan iklim harus dimulai dengan pengetahuan atas perspektif petani terhadap perubahan iklim.

4. Dilakukannya penelitian lanjutan untuk menggali faktor-faktor penentu kapasitas adaptasi perubahan iklim petani padi sawah di lokasi penelitian.

\section{DAFTAR PUSTAKA}

Adger, W.N., Dessai, S., Goulden, M.. Hulme, M., Lorenzoni, I., Nelson, D.R., Naess, L.O., Wolf, J., Wreford, A., (2009), Are There Social Limits to Adaptation to Climate Change? Climatic Change (2009) 93:335-354, DOI 10.1007/s10584-008-9520-z

Amien I., Rejekiningrum, P., Pramudia, A., Susanti. E., (1996), Effects of Interannual Climate Variability and Climate Change on Rice Yield in Java, Indonesia dalam Climate Change Vulnerability and Adaptation in Asia and the Pacific, Doi: 10.1007/978-94-017-1053-4.

Arbuckle Jr, J.G., Prokopy, L.S., Haigh, T., Hobbs, J., Knoot, T., Knutson, C., Loy, A., Mase, A.S., McGuire, J., Morton, L.W., Tyndall, J., Widhalm, M., (2013), Climate Change Beliefs, Concerns, and Attitudes toward Adaptation and Mitigation Among Farmers in The Midwestern United States, Climatic Change, DOI 10.1007/s10584-013-0707-6

Asante, F.A., Boakye, A.A., Egyir, I.S., Jatoe, J.B.D., (2009), Climate Change and Farmers' Adaptive Capacity to Strategic Innovations: the Case of Northern Ghana, International Journal of Development and Sustainability Volume 1 Number 3, December 2012, ISDS Article ID: IJDS12082403, Online ISSN: 2168-8662 www.isdsnet.com/ijds

Asplund, T., (2014), Natural Versus Anthropogenic Climate Change: Swedish Farmers' Joint Construction of Climate Perceptions, PUS 1(16), Doi: 10.1177/0963 6625145 59655

Boer, R. dan Faqih, A., (2004), Global Climate Forcing Factors and Rainfall Variability in West Java: Case Study in Bandung District, Indonesian J Agriculture Meteorology 18: 1-12.

Buys, L., Miller, E., Megen, V.K., (2011), Conceptualising Climate Change in Rural Australia: Community Perceptions, Attitudes and (in) Actions, Reg Environ Change 12: 237-248, Doi: 10.1007/s10113-011-0253-6

Chérif, S. dan Greenberg, J.H., (2013), Religious Perspectives on Climate Change in the West Ivoirian Mountainous Region dalam How the World's Religions Are Responding to Climate Change: Social Scientific Investigations (Veldman, R.G., Szasz, A. and Haluza-DeLay, R. $\quad\{E d s\}) \quad 126-138, \quad$ Routledge, https://www.book2look.com/embed/9781136181313

Dang, H.L., (2014), Adaptation to Climate Change: the Attitude and Behaviour of Rice Farmers in the Mekong Delta Vietnam, PhD Thesis, School of Agriculture, Food, and Wine, Faculty of Sciences The University of Adelaide.

Dolan, A.H., Smit, B., Skinner, M.W., Bradshaw, B., Bryant, C.R., (2001), Adaptation to Climate Change in Agriculture: Evaluation of Options, Occasional Paper No. 26, Department of Geography, University of Guelph, ISBN 0-88955-520-6, ISSN 0831-4829.

Esham, M. dan Garforth, C., (2013), Climate Change and Agricultural Adaptation in Sri Lanka. Mitig Adapt Strateg Glob Change 18:535-549, Doi: 10.1007/ s11027-012-9374-6.

FAO, (2009), "Food Security and Agricultural Mitigation in Developing Countries: Options for Capturing Synergies." FAO, Available at http://www.fao.org

Grossman, D., (2005), Observing Those Who Observe, Nieman Reports 59(4) 80-85.

Handoko I., Sugiarto, Y., Syaukat, Y., (2008), Keterkaitan Perubahan Iklim dan Produksi Pangan Strategis: Telaah Kebijakan Independen dalam Bidang Perdagangan dan Pembangunan, Bogor, SEAMEO BIOTROP.

Hassan, R. dan Nhemachena, C., (2008), Determinants of African Farmers' Strategies for Adapting to Climate Change: Multinomial Choice Analysis, AfJARE 2(1) 83 - 104.

Hoffman, A., (2011), Talking Past Each Other? Cultural Framing of Skeptical and Convinced Logics in The Climate Change Debate, Organization \& Environment 24(1) 3-33, DOI: 10.1177/1086026611404336 http://oae.sagepub.com

IPCC, (2007), Climate Change 2007: Synthesis Report. Contribution of Working Groups I, II and III to the Fourth Assessment Report of the
Intergovernmental Panel on Climate Change, (Core Writing Team, Pachauri, R.K and Reisinger, A. \{eds.\}). IPCC Geneva, Switzerland, $104 \quad$ pp., https://www.ipcc.ch/pdf/assessment-report/ar4/syr/ar4_syr _full_report.pdf

Lipińska, I., (2016), Managing the Risk in Agriculture Production: The Role of Government. Europ, Countrys 2- 2016, DOI: 10.1515/euco-2016-0007

Lorenzoni, I., Cole, N.S., Whitmarsh, L., (2007), Barriers Perceived to Engaging with Climate Change Among the Uk Public and Their Policy Implications, J GLOENVCHA 17: 445-459, Doi:10.1016/j.gloenvcha.2007.01.004.

Mabe, F.N., Sarpong, D.B., Osei-Asare, Y., (2012), Adaptive Capacities of Farmers to Climate Change Adaptation Strategies and Their Effects on Rice Production in the Northern Region of Ghana, Russian Journal of Agricultural and Socio-Economic Sciences No. 11 (11) / 2012

Monroe, M.C., $\quad$ Day, B.A., Grieser, M., (2000), Greencom Weaves Four Strands dalam Environmental Education \& Communication for a Sustainable World: Handbook for International Practitioners (Day, B.A. and Monroe, M.C. \{Eds.\}). Academy for Educational Development. USA

Moser, S.C., (2010), Communicating Climate Change: History, Challenges, Process and Future Directions, Wires Clim Change 1: 31-53, Doi: 10.1002/wcc.011.

Naylor, R.L., Battisti, D.S., Vimont, D.J., Falcon, W.P., Burke, M.B., (2007), Assesing the Risk of Climate Variability and Climate Change for Indonesian Rice Agriculture dalam Proceeding of the National Academic of Sci 114: 7752-7757, Doi: 10.1073/pnas.0701825104.

Nisbet, M.C., (2009), Communicating Climate Change: Why Frames Matter for Public Engagement, Environment: Science and Policy for Sustainable Development 51:2, 12-23, Http://dx.doi.org/10.3200/ENVT.51.2.12-23

Ozor, N., dan Cynthia, N., (2011), The Role of Extension in Agricultural Adaptation to Climate Change in Enugu State Nigeria, JAERD 3(3), Doi: 10.5897/ JAERD.

PEACE, (2007), Indonesia and Climate Charge: Current Status and Policies. Jakarta, PEACE

Peñalba, L.M., Elazegui, D.D., Pulhin, J.M., Cruz, R.V.O., (2012), Social and Institutional Dimensions of Climate Change Adaptation, Int J Climate Change Strategies and Management, http://dx.doi.org/10.1108/175686912112 48748.

Puupponen, A., Kortetmäki, T., Paloviita, A., Järvelä, M., (2015), Social Acceptance of Climate Change Adaptation in Farms and Food Enterprises: A Case Study in Finland, Int. Jrnl. of Soc. of Agr. \& Food Vol. 22, No. 2, pp. 105-123, ISSN: 0798-1759

Rambo, A.T., (1985), Information Flow in Ecological Systems: a Theoretical Basis for The Study of Environmental Communication dalam KLH-EWC-AMIC Workshop on 'Environmental Communication: Singapore, Apr 1-3 1985, Nanyang Technological University Library, Asian Mass Communication Research and Information Centre.

Rejesus, R.M., Mutuc-Hensley, M., Mitchell, P.D., Coble, C.H., Knight, T.O., (2013), U.S. Agricultural Producer Perceptions of Climate Change, Journal of Agricultural and Applied Economics 45 4(November 2013): 701-718, Southern Agricultural Economics Association.

Skambraks, A., (2014), Smallholder farmers' adaptation to climate change in zenzelima, ethiopia. a case study of female and male farmers perception of and ability to adapt to climate change in Zenzelima Ethiopia, PhD Thesis, Vienna, University of Natural Resources and Life Sciences Vienna, Department of Sustainable Agricultural Systems Division of Organic Agriculture.

Smit, B. dan Wandel, J., (2006), Adaptation, Adaptive Capacity and Vulnerability, Global Environmental Change 16, 282-292.

Syahbuddin, H., Las, I., Unadi, A., Runtunuwu, E., (2007), Identifikasi dan Delineasi Kalender Tanam dan Pola Tanam Pada Lahan Sawah Terhadap Anomali Iklim di Pulau Jawa, Laporan Akhir Penelitian pada Satuan Kerja Balai Penelitian Agroklimat dan Hidrologi, Balai Besar Litbang Sumberdaya Lahan Pertanian, Jakarta. Balitbang Pertanian Departemen Pertanian.

Thompson, J.L. dan Schweizer, S.E., (2008), The Conventions of Climate Change Communication (Paper Presented at the National Communication Association Convention), San Diego 
Salampessy, Y.L.A., D.P. Lubis, I. Amien, D. Suhardjito. 2018. Menakar Kapasitas Adaptasi Perubahan Iklim Petani Padi Sawah (Kasus Kabupaten Pasuruan Jawa Timur). Jurnal Ilmu Lingkungan, 16(1), 25-34, doi:10.14710/jil.16.1.25-34
California,
November
https://www.earthtosky.org/content/climate/PDF_Resources

20-24,

Wamsler, C. dan Brink, E.,(2015), From Adaptive Capacity to Adaptation:

Rethinking the Interface between Institutions and Citizens, UNISDR.

Weber, E.U., (2010), What Shapes Perceptions of Climate Change? WIREs Climate Change 1 (3), 332-342, DOI: 10.1002/wcc.41.

Weber, E.U. dan Stern, P.C., (2011), Public Understanding of Climate Change in the United States, American Psychological Association 0003-066X/11/\$12.00 Vol. 66 No. 4, 315-328, DOI: $10.1037 / \mathrm{a} 0023253$

Wibeck, V., (2014), Social Representations of Climate Change in Swedish Lay Focus Groups: Local or Distant, Gradual or Catastrophic? PUS 23:204, Doi: 10.1177/0963662512462787. 